\title{
Association of Waist-Height-Ratio, Waist Circumference, and Body Mass Index with Serum Testosterone Level in Apparently Healthy Men
}

\author{
Agbecha Ayu ${ }^{1, ~ *, ~ G b e r i n d y e r ~ J a m e s ~ S a a-A o n d o ~}$ \\ ${ }^{1}$ Department of Chemical Pathology, Federal Medical Center, Makurdi, Nigeria \\ ${ }^{2}$ Department of Veterinary Pathology, University of Agriculture, Makurdi, Nigeria
}

Email address:

agbecha@gmail.com (A. Ayu)

${ }^{*}$ Corresponding author

To cite this article:

Agbecha Ayu, Gberindyer James Saa-Aondo. Association of Waist-Height-Ratio, Waist Circumference, and Body Mass Index with Serum Testosterone Level in Apparently Healthy Men. Biochemistry and Molecular Biology. Vol. 4, No. 1, 2019, pp. 1-5. doi: 10.11648/j.bmb.20190401.11

Received: February 9, 2019; Accepted: March 11, 2019; Published: April 13, 2019

\begin{abstract}
Previous studies have shown that waist circumference (WC) may be a better predictor of serum testosterone level than body mass index (BMI). The determination of the waist-to-height ratio (WHt ratio) is reported to have certain advantages over other adiposity measures. Our study thus aimed at examining the utility of WHt ratio in addition to WC and BMI in determining their association with testosterone level. The case-control study involved apparently healthy male participants aged between 40 to 60 years. The study participants were divided into normal and abnormal groups according to WC, BMI, WHt ratio with their mean total testosterone level compared. The correlations of total testosterone and adiposity measures along with age adjustments were also determined. Individuals with $\mathrm{WC}>100 \mathrm{~cm}$ had a significant low $(\mathrm{P}=0.003)$ testosterone level compared to their counterparts with $\mathrm{WC}<100 \mathrm{~cm}$. A significantly lowered $(\mathrm{P}=0.042)$ testosterone was observed in the study group with BMI $>25 \mathrm{~kg} / \mathrm{m}^{2}$ compared to the group with $<25 \mathrm{~kg} / \mathrm{m}^{2}$. The study group with a WHt ratio of $>0.5$ had a significantly lower $(\mathrm{P}=0.012)$ testosterone than the group with $<0.5$. An inverse correlation of testosterone was observed with age $(\mathrm{r}=-0.567)$, BMI $(\mathrm{r}=-0.265)$, WC $(\mathrm{r}=-0.406)$, and WHt ratio $(\mathrm{r}=-0.412)$ in the apparently healthy Men studied. After adjustment for age, the correlation observed between testosterone and BMI $(\mathrm{P}=0.010)$, testosterone and WC $(\mathrm{P}=0.004)$, testosterone and $\mathrm{WHt}$ ratio $(\mathrm{P}=0.014)$ remained significant. After height adjustment, the correlation between testosterone and WHt ratio $(\mathrm{P}=0.002)$ also remained significant. In conclusion, the WHt ratio and $\mathrm{WC}$ independent of age were the best predictors of the total testosterone level in men.
\end{abstract}

Keywords: Testosterone, Waist Circumference, Body Mass Index, Waist-to-Height Ratio, Men

\section{Introduction}

Testosterone is a sex-steroidsynthesized in the testes and has biologic effects on numerous tissues. A physiological decrease in testosterone concentrations has been well documented after the fourth or fifth decade of life and has been postulated to result from a decline in both testicular and hypothalamic-pituitary function [1]. In scenarios in which the patient has a clear pathophysiologic mechanism for the hypogonadism, treatment with testosterone is nearly always recommended to alleviate symptoms of hypogonadism and maintain secondary sexual characteristics [1]. Testosterone deficiency impacts on mood and cognition (decreased sense of well being, lack of motivation, deterioration in work performance, lethargy, low mood, low self-esteem, shortterm memory, tendency to fall asleep and frequent headaches), muscle function and body composition (decreased physical energy or endurance, diminished muscle mass and strength), and sexuality (decreased interest or desire for sex, reduced quality of sexual activity, poor erectile function, limited quality of orgasm, and absent or decreased nocturnal erections). Low testosterone has been reported to be an independent predictor of cardiovascular disease, stroke, mortality and Alzheimer's disease [2, 3]. 
In males, circulating testosterone blood levels have been shown to be influenced by body weight and composition. An inverse correlation between body composition and total testosterone has been described in men of different ages [4, 5]. There has been uncertainty about how best to account for obesity using adiposity measures. Increased abdominal circumference has been described as the best indicator of central obesity, total body fat, and visceral fat, particularly in men who are more than 40 years of age [6]. Data have shown that waist circumference (WC) may be a better predictor of testosterone level than weight and body mass index (BMI) [7]. A 2010 systematic review of published studies concluded that waist-to-height ratio (WHt ratio) may be advantageous over other adiposity measures since it does not require age, sex, and ethnicity in determining the specific cut off values [8]. The present study was motivated based on emerging evidence of the use of WHt ratio in profiling body adiposity [9-11]. The present study aimed at examining the utility of WHt ratio in addition to $\mathrm{WC}$ and BMI in determining their association with testosterone level in men.

\section{Materials and Methods}

\subsection{Selection of Participants}

Male patients between 40 to 60 years of age attending general health checkup in the outpatient's department of the teaching hospital were randomly selected for the study after obtaining institutional ethical clearance. Patients with diabetes mellitus, smoking habits, history of alcohol abuse (intake of more than $30 \mathrm{~mL}$ of ethanol per day), conditions requiring any medication and any other possible cause of hypogonadism identified were excluded from the study.

\subsection{Study Design}

The case-control study involved participants divided into two groups according to $\mathrm{WC}, \mathrm{BMI}$, and $\mathrm{WHt}$ ratio. Patients with normal WC less than $100 \mathrm{~cm}$ and patients with abnormal WC over $100 \mathrm{~cm}$, based on the WHO and American Heart Association criteria for patients at high risk for metabolic disease $[12,13]$. According to BMI patients were divided into two groups, as patients with normal BMI less than $25 \mathrm{~kg} / \mathrm{m}^{2}$ and overweight patients with a BMI $25-30$ $\mathrm{kg} / \mathrm{m}^{2}$, based on the WHO and National Institutes of Health criteria for obesity classification [14]. Patients were divided into normal WHt ratio (less than 0.5) and abnormal WHt ratio (greater than 0.5 ) based on previously proposed and widely accepted cut-off values [8].

\subsection{Anthropometric Measurements}

Height was determined by a stadio meter calibrated to the nearest $0.1 \mathrm{~cm}$ and weight was measured on scales calibrated to $0.1 \mathrm{~kg}$ to calculate $\mathrm{BMI}$ (ratio of body weight in $\mathrm{kg}$ to height in $\mathrm{m}^{2}$ ) [12]. Waist circumference was measured according to WHO guidelines, at the midpoint distance between the costal margin and iliac crest in the mid-axillary line on the dominantside [12]. Waist-height-ratio was calculated by dividing WC $(\mathrm{cm})$ by height $(\mathrm{cm})$.

\subsection{Laboratory Methods}

To limit the influence of fluctuations of plasma testosterone levels due to its varied secretion, fasting blood samples for testosterone evaluation were always drawn at the same time of the day, Serum levels of total testosterone were measured using immunoassay kits.

\subsection{Statistical Methods}

The student's t-test was used to test the significant difference of the anthropometrics, total testosterone level between normal and abnormal adiposity. The WC, WHt ratio and BMI were individually correlated with total testosterone levels using Pearson's correlation analysis. Multiple linear regressions were used to analyze independent variables and to correlate age, WHt ratio, BMI and WC. All statistical tests were deemed significant at a p-value lower than 0.05 . The analytical software utilized was the statistical package SPSS version 21, IBM Armonk, New York, United States.

\section{Results}

The characteristics of the subjects are detailed in Table 1 . The mean age, BMI, WC, WHt ratio and testosterone were respectively 47.05 years, $24.62 \mathrm{~kg} / \mathrm{m}^{2}, 90.41 \mathrm{~cm}, 0.53$, and $4.70 \mathrm{ng} / \mathrm{ml}$. The mean values of anthropometrics and testosterone in different anthropometric groups are displayed in Table 2. Individuals with $\mathrm{WC}>100 \mathrm{~cm}$ had a significant low $(p=0.003)$ testosterone level and high $(p=0.000)$ BMI, WHt ratio compared to their counterparts with $\mathrm{WC}<100 \mathrm{~cm}$. A significantly lowered $(\mathrm{p}=0.042)$ testosterone and elevated $(\mathrm{p}=0.000) \mathrm{WC}$, WHt ratio were observed in the study group with $\mathrm{BMI}>25 \mathrm{~kg} / \mathrm{m}^{2}$ compared to the group with $<25 \mathrm{~kg} / \mathrm{m}^{2}$. The study group with a WHt ratio of $>0.5$ had a significantly lower $(p=0.012)$ testosterone and higher $(p=0.000)$ BMI, WC than the group with $<0.5$. Table 3 shows the correlations of anthropometric measurements and testosterone. An inverse correlation of testosterone was observed with age $(\mathrm{r}=-0.567)$, BMI $(r=-0.265)$, WC $(r=-0.406)$, and WHt ratio $(r=-0.412)$ in the apparently healthy men studied. A non-significant $(p<0.05)$ correlation was observed between age and BMI, age and WC. However a significant positive correlation existed between age and $\mathrm{WHt}$ ratio $(\mathrm{r}=0.282)$, WC and $\mathrm{BMI}$ $(\mathrm{r}=0.880)$, WC and WHt ratio $(\mathrm{r}=0.950), \mathrm{BMI}$ and $\mathrm{WHt}$ ratio $(\mathrm{r}=0.845)$. An adjusted linear regression analysis of testosterone and anthropometrics is presented in Table 4. After adjustment for age, the correlation observed between testosterone and $\mathrm{BMI}(\mathrm{P}=0.010)$, testosterone and $\mathrm{WC}$ $(\mathrm{P}=0.004)$, testosterone and WHt ratio $(\mathrm{P}=0.014)$ remained significant. After height adjustment, the correlation between testosterone and WHt ratio $(p=0.002)$ also remained significant. 
Table 1. Characteristics of the study cohort $(N=60)$.

\begin{tabular}{ll}
\hline Variables & Mean \pm SD \\
\hline Age years & $47.05 \pm 9.58$ \\
Height cm & $171.72 \pm 6.51$ \\
Weight kg & $72.70 \pm 15.84$ \\
WC cm & $90.41 \pm 10.61$ \\
BMI kg/m & $24.62 \pm 5.07$ \\
WHt ratio & $0.53 \pm 0.06$ \\
Testosterone $\mathrm{ng} / \mathrm{ml}$ & $4.70 \pm 1.19$ \\
\hline
\end{tabular}

BMI-body mass index, WHt ratio- waist-height-ratio, WC-waist circumference

Table 2. Mean total testosterone and anthropometrics in different anthropometric subgroups.

\begin{tabular}{|c|c|c|c|c|}
\hline & $W C(<100 \mathrm{~cm})$ & $(W C>100 \mathrm{~cm})$ & & \\
\hline & $\mathrm{N}=36$ & $\mathrm{~N}=\mathbf{2 4}$ & t-value & P-value \\
\hline Test. ng/ml & $5.06 \pm 1.02$ & $4.15 \pm 1.24$ & 3.066 & $0.003^{*}$ \\
\hline $\mathrm{BMI} \mathrm{Kg} / \mathrm{m}^{2}$ & $21.21 \pm 2.11$ & $29.73 \pm 3.67$ & 11.410 & $0.000^{*}$ \\
\hline WHt ratio & $0.49 \pm 0.03$ & $0.59 \pm 0.06$ & 8.520 & $0.000^{*}$ \\
\hline $\mathrm{WC} \mathrm{cm}$ & $83.36 \pm 3.92$ & $100.98 \pm 8.41$ & 10.940 & $0.000^{*}$ \\
\hline \multirow[t]{3}{*}{ Age years } & $46.31 \pm 10.22$ & $48.17 \pm 8.61$ & 0.735 & 0.466 \\
\hline & BMI $\left(<25 \mathrm{Kg} / \mathrm{m}^{2}\right)$ & BMI $\left(>25 \mathrm{Kg} / \mathrm{m}^{2}\right)$ & \multirow{2}{*}{ t-value } & \multirow{2}{*}{ P-value } \\
\hline & $\mathbf{N}=\mathbf{3 7}$ & $\mathrm{N}=\mathbf{2 3}$ & & \\
\hline Test. ng/ml & $4.94 \pm 1.09$ & $4.30 \pm 1.26$ & 2.080 & $0.042 *$ \\
\hline BMI Kg/m² & $21.20 \pm 2.04$ & $30.12 \pm 3.27$ & 13.040 & $0.000 *$ \\
\hline WHt ratio & $0.49 \pm 0.03$ & $0.59 \pm 0.06$ & 7.844 & $0.000^{*}$ \\
\hline $\mathrm{WC} \mathrm{cm}$ & $83.78 \pm 4.21$ & $101.08 \pm 8.93$ & 10.150 & $0.000^{*}$ \\
\hline \multirow[t]{3}{*}{ Age years } & $46.76 \pm 9.95$ & $47.52 \pm 9.14$ & 0.299 & 0.766 \\
\hline & WHt ratio $(<0.5)$ & WHt ratio (>0.5) & \multirow{2}{*}{ t-value } & \multirow{2}{*}{ P-value } \\
\hline & $\mathrm{N}=25$ & $\mathrm{~N}=35$ & & \\
\hline Test. ng/ml & $5.14 \pm 0.89$ & $4.37 \pm 1.29$ & 2.581 & $0.012 *$ \\
\hline BMI Kg/m² & $21.27 \pm 2.12$ & $27.01 \pm 5.22$ & 5.187 & $0.000 *$ \\
\hline WHt ratio & $0.47 \pm 0.02$ & $0.57 \pm 0.06$ & 8.260 & $0.000 *$ \\
\hline $\mathrm{WC} \mathrm{cm}$ & $81.94 \pm 3.58$ & $96.46 \pm 9.78$ & 7.081 & $0.000^{*}$ \\
\hline Age years & $43.84 \pm 9.92$ & $49.34 \pm 8.75$ & 2.270 & $0.027 *$ \\
\hline
\end{tabular}

*significant, Test.-testosterone, BMI-body mass index, WHt ratio- waist-height-ratio, WC-waist circumference

Table 3. Correlations of anthropometric measurements and testosterone.

\begin{tabular}{lllll}
\hline & Test. & Age & WC & BMI \\
\hline Age & $-0.567^{* *}$ & & & \\
WC & $-0.406^{* *}$ & 0.196 & $0.880^{* *}$ & \\
BMI & $-0.265^{* *}$ & -0.017 & $0.950^{* *}$ & $0.845^{* *}$ \\
WHt ratio & $-0.412^{* *}$ & $0.282^{*}$ & \\
\hline
\end{tabular}

**Correlation is significant at the 0.01 level (2-tailed), *Correlation is significant at the 0.05 level (2-tailed).

Test.-testosterone, BMI-body mass index, WHt ratio- waist-height-ratio, WC-waist circumference

Table 4. Adjusted linear regression analysis of testosterone and anthropometric measurements.

\begin{tabular}{llll}
\hline Testosterone & WC & BMI & WHt ratio \\
\hline Age adjustment & $\mathrm{P}=0.004^{*}$ & $\mathrm{P}=0.010^{*}$ & $\mathrm{P}=0.014^{*}$ \\
Height adjustment & - & - & $\mathrm{P}=0.002^{*}$ \\
\hline
\end{tabular}

*significant, BMI-body mass index, WHt ratio- waist-height-ratio, WC-waist circumference

\section{Discussion}

Low testosterone level is a risk factor for metabolic syndrome, type 2 diabetes, cardiovascular disease and all causes of mortality in men [15]. The objective of the present study was to correlate the WC, WHt ratio, and BMI with the levels of total testosterone.

This study observed an association of total testosterone with WC, WHt ratio, and BMI in the participants. Total testosterone (TT) level decreased as WC, WHt ratio, and BMI increased. Pearson correlation showed an inverse correlation of TT with WC, WHt ratio, and BMI. A stronger correlation of TT with WHt ratio than WC and BMI was observed in the present study.

The finding of this present study is similar to that of other studies. Data from the Massachusetts Male Aging Study 
(MMAS) [16] and the European Male Aging Study (EMAS) [17] performed in large groups of middle-aged and elderly men have shown that BMI and WC are independently associated with decreased values of total testosterone. Jaworski et al., in addition to observing an inverse association of testosterone with $\mathrm{BMI}$ and $\mathrm{WC}$, further reported a higher strength of association between abdominal circumference and TT, when compared to the association between BMI and TT [18]. The only study in the literature that determined the relationship of $\mathrm{WHt}$ ratio with testosterone showed that the WHt ratio was more strongly correlated with TT than either WC or BMI [19].

The present study observed an inverse correlation between age and testosterone, but an absent correlation of age with adiposity measures. Men's testosterone synthesis has been shown to decrease with increasing age, whereas central obesity tends to increase [20-22]. The absent correlation of age with adiposity indices implies that testosterone and adiposity impact each other based on the findings of this present study.

The association of testosterone with adiposity measures can be explained by the pathophysiological mechanisms of low testosterone in obese men. The mechanism is believed to be mediated by insulin resistance, estrogen, adipokines, and cytokines at the hypothalamus-pituitary axis, leading to a hypogonadotropichypogonadal state. Compensatory hyperinsulinemia accompanying the insulin resistant state in visceral obesity inhibits hepatic sex hormone binding globulin (SHBG) secretion which impacts negatively on bioavailable testosterone [23-24]. Ahn and colleagues found that hyperinsulinemia may directly exert a suppressive effect on testicular Leydig cell steroidogenesis [25]. In the mesenchymal cells and preadipocytes of adiposetissue of male subjects, androgens can be converted to estrogens by increased aromatase activity as a result of increased adiposetissue mass resulting in a reduction of gonadal testosterone production [26] Elevated adipokines and cytokines are produced by visceral adipose tissues which exert both paracrine and endocrine functions [27]. Several of these adipokines have been involved in the development of insulin resistance and has been shown to increase oxidative stress in the testes [28].

\section{Conclusion}

The results of this present study show that all the adiposity measures determined predict the total testosterone level independent of age. The results further suggest that, of the anthropometric measures compared in this study, WHt ratio and WC are the best predictors of total testosterone level in men.

\section{References}

[1] Bhasin S, Brito JP, Cunningham GR, Hayes FJ, Hodis HN, Matsumotom AM, et al. Testosterone therapy in men with hypogonadism: an Endocrine Society clinical practice guideline. J Clin Endocrinol Metab 2018; 103 (5): 1715- 44.
[2] Goodale T, Sadhu A, Petak S, Robbins R. Testosterone and the Heart. Methodist Debakey Cardiovasc J 2017; 13 (2): 68-72.

[3] Lv W, Du N, Liu Y, Fan X, Wang Y, Jia X, et al. Low Testosterone Level and Risk of Alzheimer's Disease in the Elderly Men: a Systematic Review and Meta-Analysis. Mol Neurobiol 2016 May; 53 (4): 2679-84. doi: 10.1007/s12035015-9315-y.

[4] Shamim MO, Ali Khan FM, Arshad R. Association between serum total testosterone and Body Mass Index in middle aged healthy men. Pak J Med Sci 2015; 31 (2): 355-9.

[5] Rotter I, Rył A, Grzesiak K, Szylińska A, Pawlukowska W, Lubkowska A. et al. Cross-Sectional Inverse Associations of Obesity and Fat Accumulation Indicators with Testosterone in Non-Diabetic Aging Men. Int J Environ Res Public Health 2018; 15 (6): 1207. Published 2018 Jun 8. doi: $10.3390 /$ ijerph15061207

[6] Jabłonowska-Lietz B, Wrzosek M, Włodarczyk M, Nowicka $\mathrm{G}$. New indexes of body fat distribution, visceral adiposity index, body adiposity index, waist-to-height ratio, and metabolic disturbances in the obese. Kardiol Pol 2017; 75 (11): 1185-1191. doi: 10.5603/KP.a2017.0149

[7] Yassin AA, Nettleship JE, Salman M, Almehmadi Y. Waist circumference is superior to weight and BMI in predicting sexual symptoms, voiding symptoms and psychosomatic symptoms in men with hypogonadism and erectile dysfunction. Andrologia 2017; 49: e12634.

[8] Browning LM, Hsieh SD, Ashwell M. A systematic review of waist-to-height ratio as a screening tool for the prediction of cardiovascular disease and diabetes: 0.5 could be a suitable global boundary value. Nutrition Research Reviews 2010; 23 (2): $247-269$.

[9] Yoo EG. Waist-to-height ratio as a screening tool for obesity and cardiometabolic risk. Korean J Pediatr 2016; 59 (11): 425431.

[10] Aguilar-Morales I, Colin-Ramirez E, Rivera-Mancía S, Vallejo M, Vázquez-Antona C. Performance of Waist-ToHeight Ratio, Waist Circumference, and Body Mass Index in Discriminating Cardio-Metabolic Risk Factors in a Sample of School-Aged Mexican Children. Nutrients 2018; 10 (12): 1850. Published 2018 Dec 1. doi: 10.3390/nu10121850

[11] Sinaga M, Worku M, Yemane T, Tegene E. Wakayo T, Girma T. et al. Optimal cut-off for obesity and markers of metabolic syndrome for Ethiopian adults. Nutr J 2018; 17 (1): 109. Published 2018 Nov 22. doi: 10.1186/s12937-018-0416-0

[12] World Health Organization. Obesity: preventing and managing the global epidemic. WHO: Geneva, Switzerland, 2000. Technical report no. 894.

[13] Grundy SM, Cleeman JI, Daniels SR, Donato KA, Eckel RH, Franklin BA, et al. American Heart Association; National Heart, Lung, and Blood Institute. Diagnosis and management of the metabolic syndrome: an American Heart Association/National Heart, Lung, and Blood Institute Scientific Statement. Circulation 2005; 112 (17): 2735-52.

[14] World Health Organization. Obesity and overweight. WHO: Geneva, Switzerland, 2018. Fact sheet

[15] Yao QM, Wang B, An XF, Zhang JA, Ding L. Testosterone level and risk of type 2 diabetes in men: a systematic review and meta-analysis. Endocr Connect 2017; 7 (1): 220-231. 
[16] Mohr BA, Bhasin S, Link CL, O'Donnell AB, McKinlay JB. The effect of changes in adiposity on testosterone levels in older men: longitudinal results from the Massachusetts male aging study. Eur J Endocrinol. 2006; 155 (3): 443-52.

[17] Tajar A, Huhtaniemi IT, O'Neill TW, Finn JD, Pye SR, Lee $\mathrm{DM}$, et al. Characteristics of androgen deficiency in late-onset hypogonadism: results from the European Male Aging Study (EMAS). J Clin Endocrinol Metab 2012; 97 (5): 1508-16.

[18] Jaworski PED, Ramos A, Nicoleit AR, Bacarin LF, Neto PO. Importance of abdominal circumference and body mass index values in predicting male hypogonadism - A practicalapproach. Arch Endocrinol Metab 2017; 61.

[19] Allan CA, Peverill RE, Strauss BJ, Forbes EA, McLachlan RI. Waist-to-height ratio as a predictor of serum testosterone in aging men with symptoms of androgen deficiency. Asian $\mathrm{J}$ Androl. 2011; 13 (3): 424-31. doi: 10.1038/aja.2011.13.

[20] Fillo J, Levcikova M, Ondrusova M, Breza J, Labas P. Importance of Different Grades of Abdominal Obesity on Testosterone Level, Erectile Dysfunction, and Clinical Coincidence. American Journal of Men's Health 2017; 11 (2) 240-245 DOI: $10.1177 / 1557988316642213$.

[21] Wu F, Tajar A, Beynon J, Pye S, Silman A, Finn J, et al. Identification of late-onset hypogonadism in middle-aged and elderly men. N Engl J Med 2010; 363: 123-135.

[22] Travison TG, Araujo AB, Kupelian V, O'Donnell AB, McKinlay JB. The relative contributions of aging, health, and lifestyle factors to serum testosterone decline in men. J Clin Endocrinol Metab. 2007; 92 (2): 549-55.
[23] Daka B, Rosen T, Jansson PA, Råstam L, Larsson CA, Lindblad U. Inverse association between serum insulin and sex hormone-binding globulin in a population survey in Sweden. Endocr Connect. 2012; 2 (1): 18-22. Published 2012 Nov 19. doi: 10.1530/EC-12-0057.

[24] Winters SJ, Gogineni J, Karegar M, Scoggins C, Wunderlich CA, Baumgartner R, et al. Sex Hormone-Binding Globulin Gene Expression and Insulin Resistance, The Journal of Clinical Endocrinology \& Metabolism 2014, 99 (12), E2780E2788, https://doi.org/10.1210/jc.2014-2640.

[25] Ahn SW, Gang GT, Kim YD, Ahn RS, Harris RA, Lee CH, et al. Insulin directly regulates steroidogenesis via induction of the orphan nuclear receptor DAX-1 in testicular Leydig cells. J Biol Chem 2013; 288 (22): 15937-46.

[26] Pelusi C \& Pasquali R. The Significance of Low Testosterone Levels in Obese Men. Curr Obes Rep 2012; 1 (4): 181-190. DOI 10.1007/s13679-012-0029-4.

[27] Kang YE, Kim JM, Joung KH, Lee JH, You BR, Choi MJ. et al. The Roles of Adipokines, Proinflammatory Cytokines, and Adipose Tissue Macrophages in Obesity-Associated Insulin Resistance in Modest Obesity and Early Metabolic Dysfunction. PLoS One 2016; 11 (4): e0154003. doi: 10.1371/journal.pone.0154003.

[28] Ouchi N, Ohashi K, Shibata R, Murohara T. Adipocytokines and obesity-linked disorders. Nagoya J Med Sci. 2012; 74 (12): $19-30$ 